[RADIOCARBON, VOL 28, No. 2A, 1986, P 473-485]

\title{
DATING OF HOLOCENE STRATIGRAPHY WITH SOLUBLE AND INSOLUBLE ORGANIC FRACTIONS AT THE LUBBOCK LAKE ARCHAEOLOGICAL SITE, TEXAS: AN IDEAL CASE STUDY
}

\author{
HERBERT HAAS*, VANCE HOLLIDAY**, \\ and ROBERT STUCKENRATH†
}

\begin{abstract}
The Lubbock Lake site, on the Southern High Plains of Texas, contains one of the most complete and best-dated late Quaternary records in North America. A total of 117 ${ }^{14} \mathrm{C}$ dates are available from the site, determined by the Smithsonian and SMU Laboratories. ()f these dates, 84 have been derived from residues (humin) and humates (humic acids) of organic-rich marsh sediments and A horizons of buried soils. Most of the ages are consistent with dates determined on charcoal and wood, and with the archaeologic and stratigraphic record. The dates on the marsh sediments are approximate points in time. Dates from the top of buried A-horizons are a maximum for burial and in many cases are close to the actual age of burial. Dates from the base of the A-horizons are a minimum for the beginning of soil formation, in some cases as much as several thousand years younger than the initiation of pedogenesis. A few pairs of dates were obtained from humin and humic acid derived from split samples; there are no consistencies in similarities or differences in these age pairs. It also became apparent that dates determined on samples from scraped trench walls or excavations that were left open for several years are younger than dates from samples taken from exactly the same locations when the sampling surfaces were freshly excavated.
\end{abstract}

\section{INTRODUCTION}

The Lubbock Lake site, in northwestern Texas, contains a cultural, geologic, pedologic, palcontologic, and paleobotanic record beginning ca 11,000 years BP and continuing through the founding of the city of Lubbock near the end of the last century. The site has one of the most complete late Quaternary records in North America (Holliday et al, 1983, 1985), which serves as a model for the latest Pleistocene and Holocene cultural and environmental history of the Southern High Plains.

Establishing the cultural chronology and geochronology of the site is essential in reconstructing the local and regional late Quaternary history. This requires frequent use of ${ }^{14} \mathrm{C}$ dating but relatively few of the traditional and most reliable dating materials, eg, charcoal and wood, have been recovered from the site. Shell and bone are much more abundant but have been avoided as much as possible due to the uncertainties in interpreting ages from these materials. Since the site contains a considerable amount of organic-rich sediments and soils, most of the ${ }^{14} \mathrm{C}$ dates were determined on these materials.

Techniques and problems involving the dating of the soluble and insoluble fractions of organic-rich sediments and soils were discussed previously (Burleigh, 1974; Alexander \& Price, 1980; Geyh, Benzler \& Roeschmann, 1971; Goh \& Malloy, 1978; Matthews, 1980; Scharpenseel, 1971, 1979; Sheppard et al, 1979; Cambell et al, 1967). We have encountered several of these common difficulties as well as others that may be unique to Lubbock Lake. In spite of numerous uncertainties, ages determined on the organic-rich sediments and ages measured on charcoal and wood or

* Radiocarbon Laboratory, Institute for the Study of Farth and Man, Southern Methodist University, Dallas, Texas 75275

** Departments of Geography and Anthropology, Texas A \& M University, College Station, Texas 77843

+ Radiocarbon Laboratory, Smithsonian Institution, Rockville, Maryland 20852 
derived from stratigraphic and archaeologic evidence show generally good agreement.

\section{SETTING AND LATE QUATERNARY HISTORY}

The Lubbock Lake site is in the city of Lubbock, Lubbock County, Texas, in the east-central part of the semi-arid Southern High Plains (Fig 1). The site is within an entrenched meander of Yellowhouse Draw, an ephemeral tributary of the Brazos River. The site was discovered in 1936 during the excavation of a U-shaped reservoir cut along the inside of the meander. The cut exposed late Quaternary fill containing abundant archaeologic material (Holden, 1974). Most of the archaeologic excavations were concentrated along the walls of this cut (Fig 1) which provide excellent stratification. Numerous trenches were also dug along Yellowhouse Draw upstream, downstream, and near the 1936 excavation (Fig 1).

Sedimentologic, pedologic, cultural, and environmental data at Lubbock Lake were discussed elsewhere (Holliday et al, 1983, 1985; Holliday, 1982, 1983, 1985a, b, c; Johnson, 1976, 1983; Stafford, 1981). The

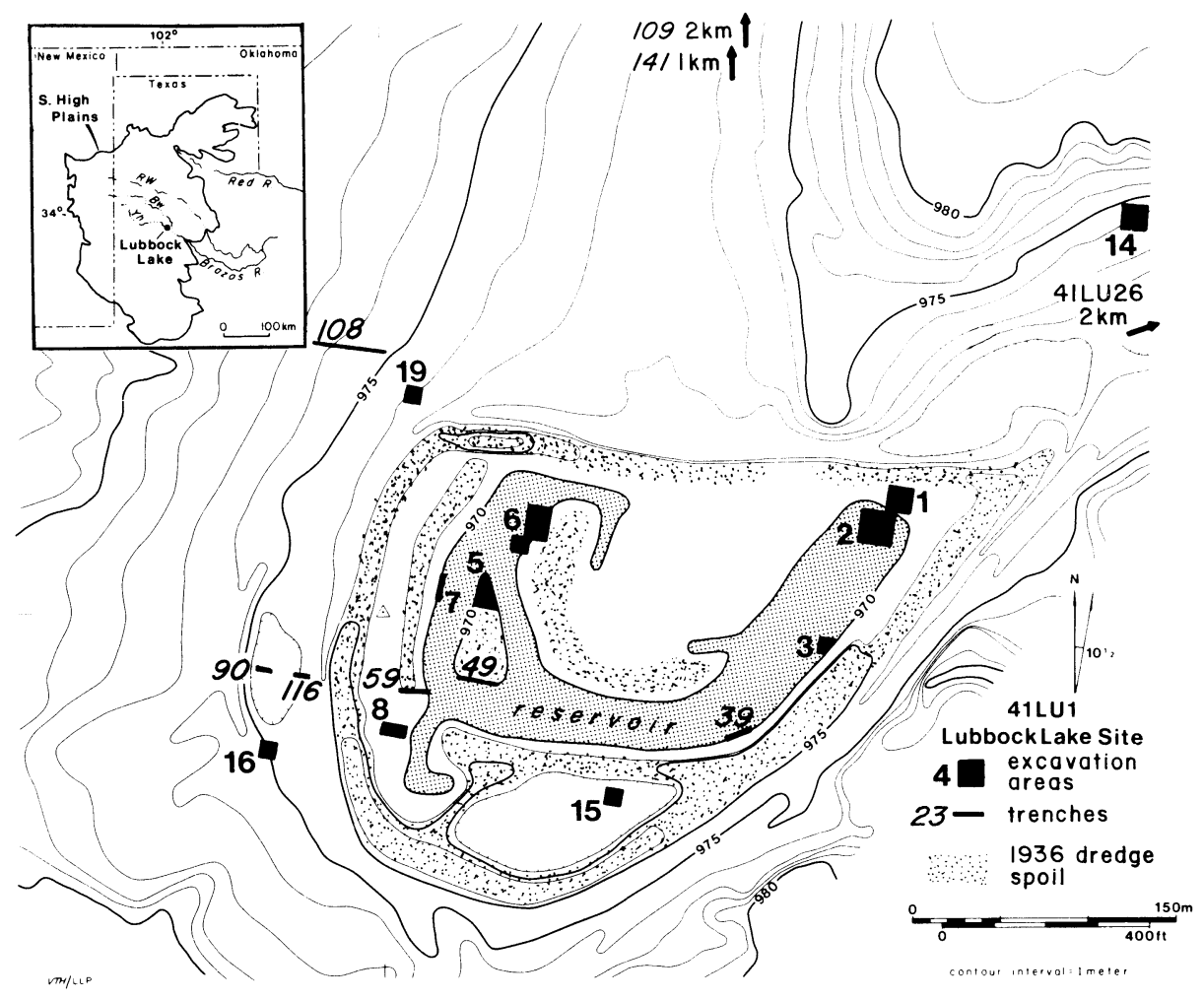

Fig 1. Topographic map of the Lubbock Lake site reservoir cut with an entrenched meander of Yellowhouse Draw (contours within the reservoir not shown). The excavation areas and trenches sampled for the ${ }^{14} \mathrm{C}$ dates listed in Table 1 are shown. The inset shows the location of the site on the Southern High Plains. 


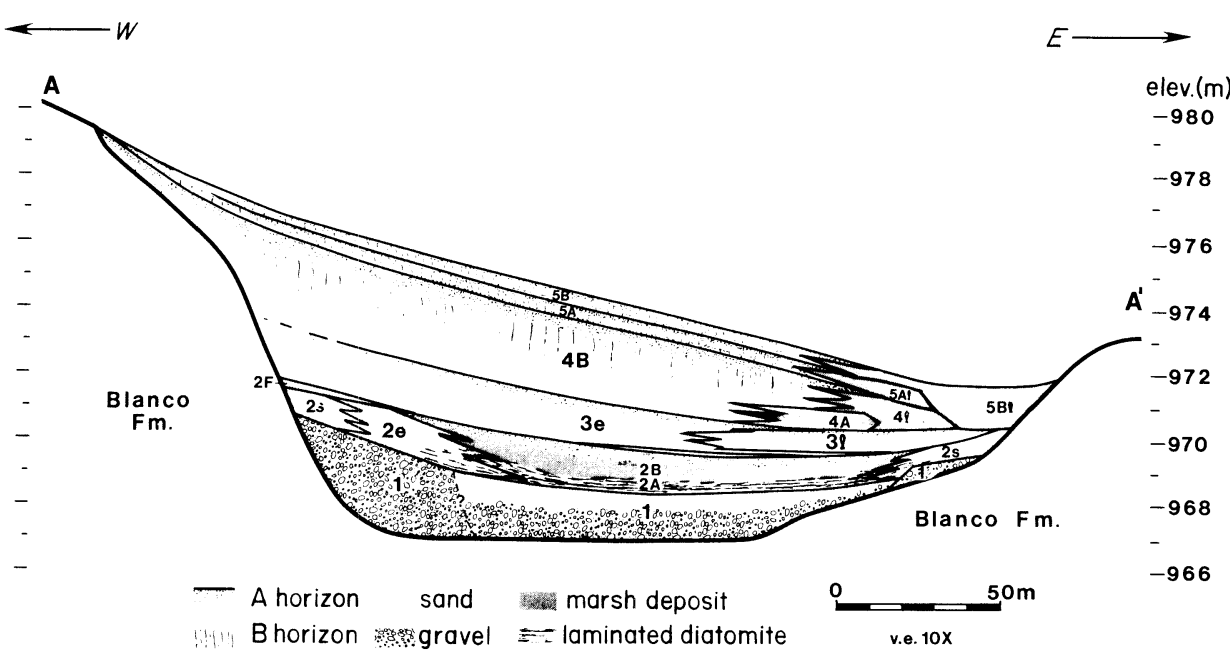

Fig 2. Generalized geologic cross-section of the Lubbock Lake site on the west side of Yellowhouse Draw. Vertical subdivisions of strata are identified by uppercase letters in alphabetical order oldest to youngest. Facies changes are indicated by lowercase letters as follows: $\mathrm{e}=$ eolian; $\mathrm{l}$ = lacustrine; $\mathrm{s}=$ slopewash.

entrenchment of Yellowhouse Draw ended in the latest Pleistocene. Since then, it has been filling episodically with a variety of sediments containing cultural, floral, and faunal remains (Figs 2, 3).

Five principle strata were identified, 1 (oldest) to 5 (youngest), as well as substrata (Fig 2). Soils formed in these units were named and several facies within the strata were identified (Fig 3).

The juxtaposition of the reservoir cut and trenches with complex stratigraphic relationships presented problems in geologic correlations from one exposure to another. The ${ }^{14} \mathrm{C}$ dating program was quite important in establishing these correlations.

\section{RADIOCARBON SAMPLES AND SAMPLING PROCEDURES}

At the end of $1984,117{ }^{14} \mathrm{C}$ dates were determined from the Lubbock Lake site, almost all measured by Southern Methodist University (SMU) and the Smithsonian Institution (SI) laboratories (Holliday et al, 1983, 1985). Only 13 samples were charcoal and 4 were wood, representing nearly all of such materials found at the site. Bone was abundant but only 12 samples were selected for dating because of often uncertain results (Taylor \& Slota, 1979). A number of the bone dates were experimental (Haas \& Banewicz, 1980; Holliday et al, 1985) and several were determined in the first decade of ${ }^{14} \mathrm{C}$ dating (Holliday et al, 1983). Shell was common in some strata, but used for only 4 dates, 2 of which were determined in 1957 at Lamont and 1962 at Isotopes, Inc, when dating was done on solid carbon (Holliday et al, 1983). Two samples were dated only recently due to problems inherent in dating shell (Michels, 1973; Taylor \& Slota, 1979).

Eighty-four dates (Table 1) were from organic-rich lacustrine and 


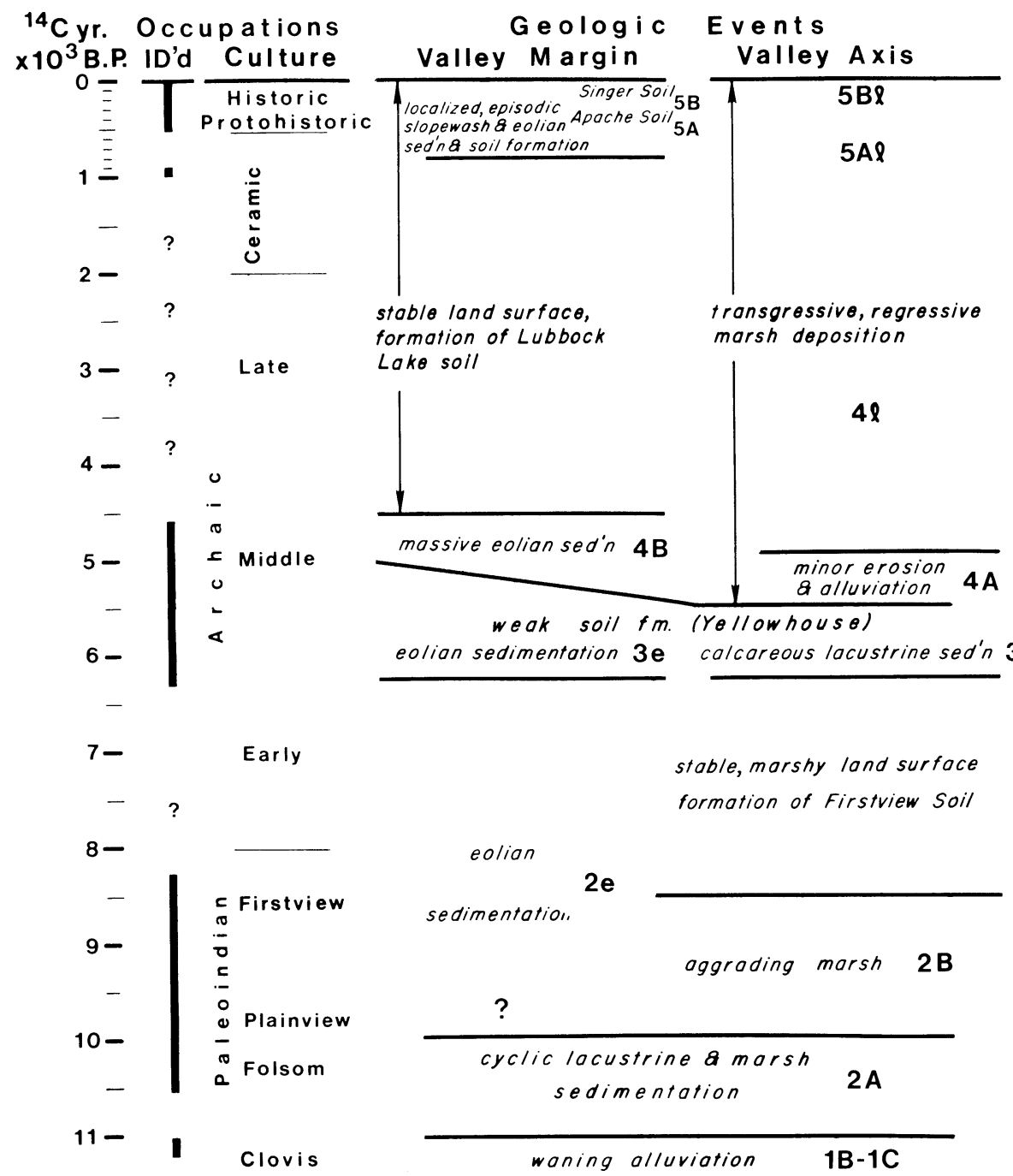

Fig 3. Schematic illustration of the geologic and cultural history of Lubbock Lake (the five named soils are also indicated) (Holliday et al, 1985, Fig 4).

marsh sediments (57 samples) and organic-rich soil A-horizons (27 samples). There were two types of sediments:

1) measured by volume, most of the sediments were up to $1 \mathrm{~m}$ thick, clayey, homogeneous deposits which accumulated in a slowly aggrading environment,

2) thin lenses, $10 \mathrm{~cm}$ thick, clayey, organic-rich material deposited relatively rapidly. Most of these lenses were within the diatomite (2A) and the shore facies (2s) of Stratum 2.

Ages on these samples are considered approximate. There was 
TABLE 1

${ }^{14} \mathrm{C}$ dates on wood, charcoal, and organic-rich soils and sediments from fresh exposures at Lubbock Lake

\begin{tabular}{|c|c|c|c|c|}
\hline Substratum & Lab no. & Age (yr BP) & Area & Material \\
\hline \multirow[t]{3}{*}{$5 \mathrm{Bl}$} & SMU-716 & $210 \pm 40$ & 6 & Wood \\
\hline & SMU-831 f* & $390 \pm 50$ & 6 & Humic acid (marsh sediment) \\
\hline & SMU-715 & $400 \pm 110$ & 6 & Wood \\
\hline $5 \mathrm{~B}$ & SMU-343 & $160 \pm 60$ & 7 & Humic acid (modern A horizon) \\
\hline \multirow[t]{12}{*}{$5 \mathrm{~A}$} & SMU-314 & $720 \pm 40$ & 7 & Humic acid (buried A horizon) \\
\hline & SMU-968 & $440 \pm 40$ & 7 & Charcoal \\
\hline & SMU-970 & $380 \pm 50$ & 7 & Charcoal \\
\hline & SMU-893f & $450 \pm 50$ & 7 & Charcoal \\
\hline & SMU-345 & $300 \pm 60$ & 8 & Charcoal (same as SI-2700) \\
\hline & SI-2700 & $380 \pm 40$ & 8 & $\begin{array}{l}\text { Charcoal (same as SMU-345) } \\
\text { Charcoal }\end{array}$ \\
\hline & SI-2701 & $505 \pm 55$ & 8 & $\begin{array}{l}\text { Charcoal } \\
\text { Humin (buried A horizon) }\end{array}$ \\
\hline & SI-3208 & $640 \pm 75$ & 8 & $\begin{array}{l}\text { Humin (buried A horizon) } \\
\text { Charcoal }\end{array}$ \\
\hline & SI-2704 & $315 \pm 50$ & 14 & $\begin{array}{l}\text { Charcoal } \\
\text { Charcoal }\end{array}$ \\
\hline & $\begin{array}{l}\text { SI-2703 } \\
\text { SMU-546 }\end{array}$ & $\begin{array}{l}285 \pm 60 \\
320 \pm 60\end{array}$ & $\begin{array}{l}15 \\
19\end{array}$ & $\begin{array}{l}\text { Charcoal } \\
\text { Charcoal }\end{array}$ \\
\hline & $\begin{array}{l}\text { SMU-546 } \\
\text { SMU-555 }\end{array}$ & $\begin{array}{l}320 \pm 60 \\
220 \pm 50\end{array}$ & $\begin{array}{l}19 \\
\operatorname{Tr} 108\end{array}$ & $\begin{array}{l}\text { Charcoal } \\
\text { Humic acid (buried A horizon) }\end{array}$ \\
\hline & $\begin{array}{l}\text { SMU-555 } \\
\text { SMU-698 }\end{array}$ & $600 \pm 50$ & $\begin{array}{l}1 \text { 1r108 } \\
\text { Tr108 }\end{array}$ & $\begin{array}{l}\text { Humic acid (buried A horizon) } \\
\text { Humic acid (marsh sediment) }\end{array}$ \\
\hline \multirow[t]{10}{*}{$4 \mathrm{~B}$} & SMU-1090 f & $1270 \pm 40$ & 7 & Humic acid (buried A horizon) \\
\hline & SI-4169 & $880 \pm 70$ & 8 & Humin (buried A horizon) \\
\hline & SI-3201 & $1215 \pm 65$ & $\operatorname{Tr} 59$ & Humin (buried A horizon; top) \\
\hline & SI-4174 & $1955 \pm 75$ & $\operatorname{Tr} 59$ & Humin (bottom A horizon; top) \\
\hline & SMU-534 & $870 \pm 40$ & $\operatorname{Tr} 108$ & Humic acid (buried A horizon; top) \\
\hline & SMU-65l & $890 \pm 70$ & $\operatorname{Tr} 108$ & Humic acid (buried A horizon; top) \\
\hline & SMU-1177 f & $1550 \pm 50$ & $\operatorname{Tr} 108$ & Humic acid (buried A horizon; top) \\
\hline & SMU-1 191 f & $2070 \pm 130$ & $\operatorname{Tr} 108$ & Humic acid (buried A horizon; middle) \\
\hline & SI-4171 & $4700 \pm 65$ & 16 & Ash and Humin (same as SMU-492) \\
\hline & SMU-492 & $4960 \pm 50$ & 16 & Ash and humic acid (same as SI-4171) \\
\hline $4 \mathrm{~A}$ & SMU-1200 f & $5270 \pm 150$ & $\operatorname{Tr} 116$ & Humic acid (marsh sediment) \\
\hline \multirow[t]{7}{*}{41} & SI-4588 & $980 \pm 60$ & 1 & Humin (marsh sediment) \\
\hline & SI-4971 & $1910 \pm 75$ & Tr109 & Humin (marsh sediment) \\
\hline & SI-4970 & $5010 \pm 95$ & Tr109 & Humin (marsh sediment) \\
\hline & SMU-697 & $2600 \pm 50$ & $\operatorname{Tr} 108$ & Humic acid (marsh sediment) \\
\hline & SI-4972 & $2500 \pm 165$ & $\operatorname{Tr} 141$ & Humin (marsh sediment) \\
\hline & SI-3206 & $3925 \pm 80$ & $\operatorname{Tr} 39$ & Humin (marsh sediment) \\
\hline & SI-3205 & $5545 \pm 100$ & $\operatorname{Tr} 39$ & Humin (marsh sediment) \\
\hline 31 & SMU-1093 f & $5220 \pm 50$ & $\operatorname{Tr} 49$ & Humic acid (buried A horizon; top) \\
\hline \multirow[t]{2}{*}{$3 e$} & SMU-531 & $4900 \pm 60$ & $\operatorname{Tr} 108$ & Humic acid (buried A horizon; top) \\
\hline & SMU-545 & $5770 \pm 80$ & $\operatorname{Tr} 108$ & Humic acid (marsh sediment) \\
\hline \multirow[t]{7}{*}{ 2B (upper) } & SMU-544 & $6400 \pm 80$ & $\operatorname{Tr} 108$ & Humic acid (buried A horizon; top) \\
\hline & SI-4178 & $6705 \pm 95$ & 6 & Humin (buried A horizon; top) \\
\hline & SMU-262 & $7970 \pm 80$ & 3 & Humic acid (buried A horizon; middle) \\
\hline & SMU-302 & $7890 \pm 100$ & 3 & Humic acid (buried A horizon; bottom) \\
\hline & SI-3204 & $7255 \pm 75$ & $\operatorname{Tr} 90$ & Humin (marsh sediment) \\
\hline & SMU $-830 \mathrm{f}$ & $8210 \pm 240$ & 6 & Humic acid (marsh sediment) \\
\hline & SI-4177 & $8655 \pm 90$ & 6 & Humin (marsh sediment) \\
\hline \multirow[t]{6}{*}{ (lower) } & SMU-275 & $9960 \pm 80$ & 2 & Humic acid (marsh sediment) \\
\hline & SMU-828 & $9870 \pm 140$ & 6 & Humic acid (marsh sediment) \\
\hline & SI-4974 & $9605 \pm 195$ & 6 & Humin (marsh sediment) \\
\hline & SMU-728 & $9990 \pm 100$ & 6 & Humic acid (marsh sediment) \\
\hline & SI-4179 & $9075 \pm 100$ & 5 & Humin (marsh sediment; same SMU-829) \\
\hline & SMU-829 f & $9170 \pm 80$ & 5 & Humic acid (same as SI-4179) \\
\hline $2 \mathrm{e}$ & SMU-1192f & $8730 \pm 240$ & $\operatorname{Tr} 108$ & Humic acid (marsh sediment) \\
\hline $2 \mathrm{sLBc}$ & SMU-699 & $9780 \pm 100$ & 5 & Humic acid (marsh sediment) \\
\hline $2 \mathrm{sLBb}$ & SMU-1261 f & $9950 \pm 120$ & 5 & Humic acid (marsh sediment) \\
\hline 2A (upper) & SI-3203 & $10015 \pm 75$ & $\operatorname{Tr} 90$ & Humin (marsh sediment) \\
\hline 2ALB 4 & SI-4975 & $9905 \pm 140$ & 6 & Humin (marsh sediment) \\
\hline \multirow[t]{3}{*}{ 2ALB2 } & SMU-251 & $10060 \pm 70$ & 3 & Humic acid (marsh sediment) \\
\hline & SI-3200 & $10360 \pm 80$ & 6 & Humin (marsh sediment) \\
\hline & SI-4976 & $10195 \pm 165$ & 6 & Humin (marsh sediment) \\
\hline \multirow{3}{*}{$1 \mathrm{~B}$} & SMU-285 & $10530 \pm 90$ & 2 & Humic acid (diatomite) \\
\hline & SMU-263 & $11100 \pm 80$ & 41 LU26 & Wood \\
\hline & SMU-548 & $11100 \pm 100$ & 2 & Wood \\
\hline
\end{tabular}

* f indicates dates corrected for fractionation 
undoubtedly some mixing and uneven rates of accumulation as the material was deposited, but the geologic and archaeologic evidence suggests that resulting variations in age would be smaller than the overall uncertainty of the sediment dating technique. Organic material in the A-horizons was incorporated into the surface of the soil parent material during a period of landscape stability. A ${ }^{14} \mathrm{C}$ age from such "homogenized" horizons is the "mean residence time" of organic material in this layer, plus the time since burial by overlying sediments (Scharpenseel, 1971). Most samples from buried A-horizons were taken in pairs: 1) from the top of the horizon, in order to determine the maximum age of burial by overlying sediments and, 2) from the base of the horizon, to provide a minimum age for the deposit in which the soil formed.

Sediment and soil samples used for ${ }^{14} \mathrm{C}$ dating were taken from walls or floors in the excavation areas. Along the circumference of the reservoir and along Yellowhouse Draw trenches were used for sampling. Samples were collected with metal tools and placed in airtight plastic bags, holding ca $750 \mathrm{~g}$ (dry weight). Sample size was 1 or 2 bags for organic-rich sediments and 3 bags for buried A-horizons.

\section{LABORATORY PROCEDURES AND INTERLABORATORY COMPARISONS}

The two ${ }^{14} \mathrm{C}$ laboratories participating in this research used very different dating procedures. The Smithsonian laboratory used nonsoluble organic residues contained within the matrix and the SMU laboratory used base-soluble humic acids.

The Smithsonian laboratory pretreatment is as follows:

1) Grind sample to powder.

2) Stir with $6 \mathrm{~N}$ HC1 to remove initial carbonates and to reduce sample bulk; filter and wash with distilled water.

3) Boil in $2 \% \mathrm{NaOH}$ for 30 minutes; filter and wash with distilled water.

4) Re-acidify overnight with $2 \mathrm{~N} \mathrm{HCl}$ filter and wash with distilled water.

5) Oven dry at $105 \mathrm{C}$.

The following procedure was used at the SMU laboratory for the extraction of humic acids:

1) Break large soil pieces in mortar, handpick roots and carbonaceous inclusions.

2) Dissolve sediment in distilled water and remove floating roots with spoon and suction apparatus. Frequent stirring will release additional roots trapped in the sediment.

3) Acidify sample with HC1 (ca $4 \mathrm{~N}$ ) to hydrolize carbonates. Digest acidified sample in hot water bath for 8 hours. Replenish HC1 if its concentration is lowered through reaction.

4) Neutralize sample through decantations and refillings of container with distilled water.

5) Boil in $5 \mathrm{~L}$ of $5 \% \mathrm{NaOH}$ solution for 8 hours. Container remains covered and sample is stirred every hour. 
6) Humate solution decanted into glass bottles and kept sealed. Let suspended clay particles settle for one day, continue to decant solution between bottles until no more settled clays are visible. These decantations are performed in lieu of vacuum filtering in Buchner funnels. Filtering clay-rich solutions with glass filter paper is a very slow process, which may extend over more than a week.

7) Residual humates in sediment are diluted with distilled water. These diluted solutions are treated as indicated in 6) and are repeated until the strength of these solutions has declined to the appearance of weak coffee.

8) The combined and purified humate solutions are acidified with phosphoric acid (ca 2\%). After floculation and settling of humates, the solutions are filtered. The filter cake of retained humates is then dried at $85^{\circ} \mathrm{C}$ for 24 hours.

9) The remaining sediment is neutralized through numerous decantations and refills of distilled water. Final procedure is acidification with phosphoric acid and drying. The sample is then stored for possible later dating of the residue fraction.

The yield of humic acids varies according to the stratigraphic position of the sample. From an A-horizon soil sample of $2 \mathrm{~kg}$ dry weight, ca $35 \mathrm{~g}$ of quite pure humates can be expected. These humates have the appearance of shiny, angular and black crystals. Ash content, after combustion, is ca $60 \%$ and is mostly clay. Carbon yield, as $\mathrm{CO}_{2}$, of the organic content usually lies between 40 and $50 \%$, thus, 10 to $13 \mathrm{~L}$ of $\mathrm{CO}_{2}$ may be expected.

At Lubbock Lake, sediments not classified as soils have a much lower organic content. Complete extraction using the SMU method yields a dried humate filter cake with 80 to $90 \%$ clay content. Up to $150 \mathrm{~g}$ of this dull black humate-clay concentrate must be combusted for a sample size of 3 to $5 \mathrm{~L}$ $\mathrm{CO}_{2}$ gas.

Data on organic carbon content is available from some of the ${ }^{14} \mathrm{C}$ samples (Table 2). The measured organic carbon contents range from $1.4 \%$ to

TABLE 2

Radiocarbon dates with available organic carbon data*

\begin{tabular}{lcc}
\hline Lab no. & Date & OC \%** \\
\hline SMU-343 & $160 \pm 60$ & 1.4 \\
SI-4971 & $1910 \pm 75$ & 0.7 \\
SMU-314 & $720 \pm 40$ & 0.7 \\
SI-4972 & $2500 \pm 165$ & 0.6 \\
SMU-1 91 & $2070 \pm 130$ & 0.5 \\
SMU-1090 & $1270 \pm 40$ & 0.5 \\
SI-4970 & $5010 \pm 95$ & 0.4 \\
SI-3208 & $640 \pm 75$ & 0.4 \\
SMU-1192 & $8730 \pm 240$ & 0.3 \\
SI-4174 & $1955 \pm 75$ & 0.3 \\
SI-3201 & $1215 \pm 65$ & 0.3 \\
SI-4169 & $880 \pm 70$ & 0.2 \\
SMU-1200 & $5270 \pm 150$ & 0.1 \\
\hline
\end{tabular}

* From Holliday (1982)

** Walkley-Black technique (Allison, 1965) 
$0.1 \%$, mostly from buried soil A-horizons, and span most of the Holocene record.

Only one pair of humate and residue dates, a diatomite sample from substratum 2ALB2 (Table 3), was measured by the SMU laboratory. The humate date, $10,060 \pm 70 \mathrm{BP}$, appears correct according to stratigraphic position. The residue date $(7840 \pm 170 \mathrm{BP})$ is much too young. A possible explanation is that the diatomite, slightly more porous than over-and underlying clayey strata, may have functioned as an aquifer filtering younger organic particles from slowly migrating ground water.

Comparison dates measured by the Smithsonian and SMU laboratories are shown in Table 3. The pair of dates on charcoal shows that there is no significant calibration discrepancy between the two laboratories. The remaining dates fail to demonstrate a consistent difference between humate and residue ages. In these comparisons, each laboratory applied its preferred dating method to a split sediment sample. Two humate ages are older by at least $2 \sigma, 1$ residue age is older by $3 \sigma$, and 1 pair of dates is within $1 \sigma$. All of these samples were taken from fresh exposures.

Fractionation corrections were applied systematically to all SMU dates since 1981 (Table 4). Most earlier SMU dates and all Smithsonian dates are therefore lacking this correction.

\section{GENERAL DISCUSSION OF RADIOCARBON DATES}

${ }^{14} \mathrm{C}$ samples of organic-rich soils and sediments of the Lubbock Lake site were collected from 1974-1984. The dates include duplicate analyses made by both laboratories on split samples as well as analyses made on samples re-collected from exactly the same locations and positions at intervals of one to several years.

Generally, the ${ }^{14} \mathrm{C}$ sequence determined from these materials is consistent with stratigraphic and archaeologic evidence and with the few available wood and charcoal dates. There seems to be no correlation between the organic content and the reliability of the dates (Table 2).

TABLE 3

List of pairs of residue and humate and charcoal dates

\begin{tabular}{|c|c|c|c|c|}
\hline Locale & Substrat & Residue & Humate & Material \\
\hline Area 3 & 2AIBC & $\begin{array}{l}7840 \pm 170 \\
(S M U-247)\end{array}$ & $\begin{array}{r}10,060 \pm 70 \\
(S M U-251)\end{array}$ & Organic lens in diatomite \\
\hline Area 5 & $2 \mathrm{~B}$, base & $\begin{array}{c}9075 \pm 100 \\
(\mathrm{SI}-4179)\end{array}$ & $\begin{array}{l}9170 \pm 80 \\
(\text { SMU }-829)\end{array}$ & Organic marsh sediment \\
\hline Area 6 & $2 \mathrm{~B}$, base & $\begin{array}{c}9605 \pm 195 \\
(S I-4974)\end{array}$ & $\begin{array}{c}9990 \pm 100 \\
(\mathrm{SMU}-728)\end{array}$ & Organic marsh sediment \\
\hline Area 6 & $2 \mathrm{~B}$, middle & $\begin{array}{r}8655 \pm 90 \\
(\text { SI-4177) }\end{array}$ & $\begin{array}{c}7980 \pm 180 \\
(\mathrm{SMU}-827)\end{array}$ & Organic marsh sediment \\
\hline \multirow[t]{2}{*}{ Area 16} & $4 \mathrm{~B}$ & $\begin{array}{r}4700 \pm 65 \\
(\mathrm{SI}-4171)\end{array}$ & $\begin{array}{l}4960 \pm 50 \\
(S M U-492)\end{array}$ & Ash \\
\hline & & \multicolumn{2}{|c|}{ Charcoal } & \\
\hline Area 8 & $5 \mathrm{~A}$ & $\begin{array}{l}380 \pm 40 \\
(\text { SI-2700) }\end{array}$ & $\begin{array}{c}300 \pm 60 \\
(\mathrm{SMU}-345)\end{array}$ & \\
\hline
\end{tabular}


TABLE 4

Stable carbon isotope ratios

\begin{tabular}{rlll}
\hline $\begin{array}{l}\text { SMU } \\
\text { no. }\end{array}$ & Substratum & \multicolumn{1}{c}{ Material } & ${ }^{13} \mathrm{C} /{ }^{12} \mathrm{C}, \% 0$ \\
\hline 831 & 5BL & Humic acid (marsh sediment) & -25.5 \\
1090 & 4B & Humic acid (buried A horizon) & -14.0 \\
1177 & 4B & Humic acid (buried A horizon top) & -15.5 \\
1191 & 4B & Humic acid (buried A horizon middle) & -15.7 \\
1200 & 4A & Humic acid (marsh sediment) & -17.3 \\
1093 & 3L & Humic acid (buried A horizon top) & -14.0 \\
830 & 2B (upper) & Humic acid (marsh sediment) & -22.8 \\
829 & 2B (lower) & Humic acid (marsh sediment) & -22.7 \\
1261 & 2sLBb & Humic acid (marsh sediment) & -23.2 \\
893 & 5A & Charcoal & -25.5 \\
263 & 1B & Wood & -27.4 \\
\hline
\end{tabular}

There are some discrepancies which are especially noteworthy in duplicate analyses. In investigating these inconsistent dates, all aspects of sampling and processing as well as timing and circumstance of each action were considered. It became evident that dates derived from samples taken in freshly cut trenches or newly opened excavation areas were most reliable. Resampling and dating these exposures in subsequent years resulted in generally younger ages, although a few samples from many old exposures were contaminated even though the exposures were cleaned before resampling. Contamination of the walls of the excavation from penetration is not well understood; thus, a new research program is being planned to investigate this phenomena. Further, Table 5 demonstrates that repeated humic acid dates from Area 3 are not as different (maximum $440 \mathrm{yr}$ ) as residue dates repeated in other areas (750-1300 yr difference).

Because of these discrepancies, only dates derived from soils and sediments of freshly cut exposures were included in Table 3 and Figure 4, and were considered in the discussions of the dates in the final section. All wood samples, most charcoal samples, and a single shell sample produced internally consistent ${ }^{14} \mathrm{C}$ dates.

TABLE 5

Resampling chronology and resultant dates at Lubbock Lake

\begin{tabular}{llclll}
\hline Substratum & Location & Age: Date BP & Lab \# & Area exposed & Sample taken \\
\hline 2ALB2 & Area 6 & $10,360 \pm 80$ & SI-3200 & Summer, 1976 & July, 1976 \\
& & $9,040 \pm 90$ & SI-4592 & Summer, 1976 & June, 1980 \\
& & $10,195 \pm 165$ & SI-4976 & July, 1981 & July, 1981 \\
2ALB2 & Area 3 & $10,060 \pm 170$ & SMU-251 & Summer, 1973 & Summer, 1974 \\
& & $10,160 \pm 80$ & SMU-846 & Summer, 1973 & April, 1976 \\
& & $9,720 \pm 80$ & SMU-975 & Summer, 1973 & August, 1979 \\
2ALB4 & Area 6 & $9,115 \pm 70$ & SI-3199 & Summer, 1976 & July, 1976 \\
& & $8,335 \pm 80$ & SI-4593 & Summer, 1976 & June, 1980 \\
& & $9,905 \pm 140$ & SI-4975 & July, 1981 & July, 1981 \\
4L (upper) & Tr 39 & $3,925 \pm 80$ & SI-3206 & Summer, 1976 & Sept, 1976 \\
& & $3,175 \pm 85$ & SI-4175 & Summer, 1976 & August, 1979 \\
4L (lower) & Tr 39 & $5,545 \pm 100$ & SI-3205 & Summer, 1976 & Sept, 1976 \\
& & $4,355 \pm 80$ & SI-4176 & Summer, 1976 & August, 1979 \\
\hline
\end{tabular}




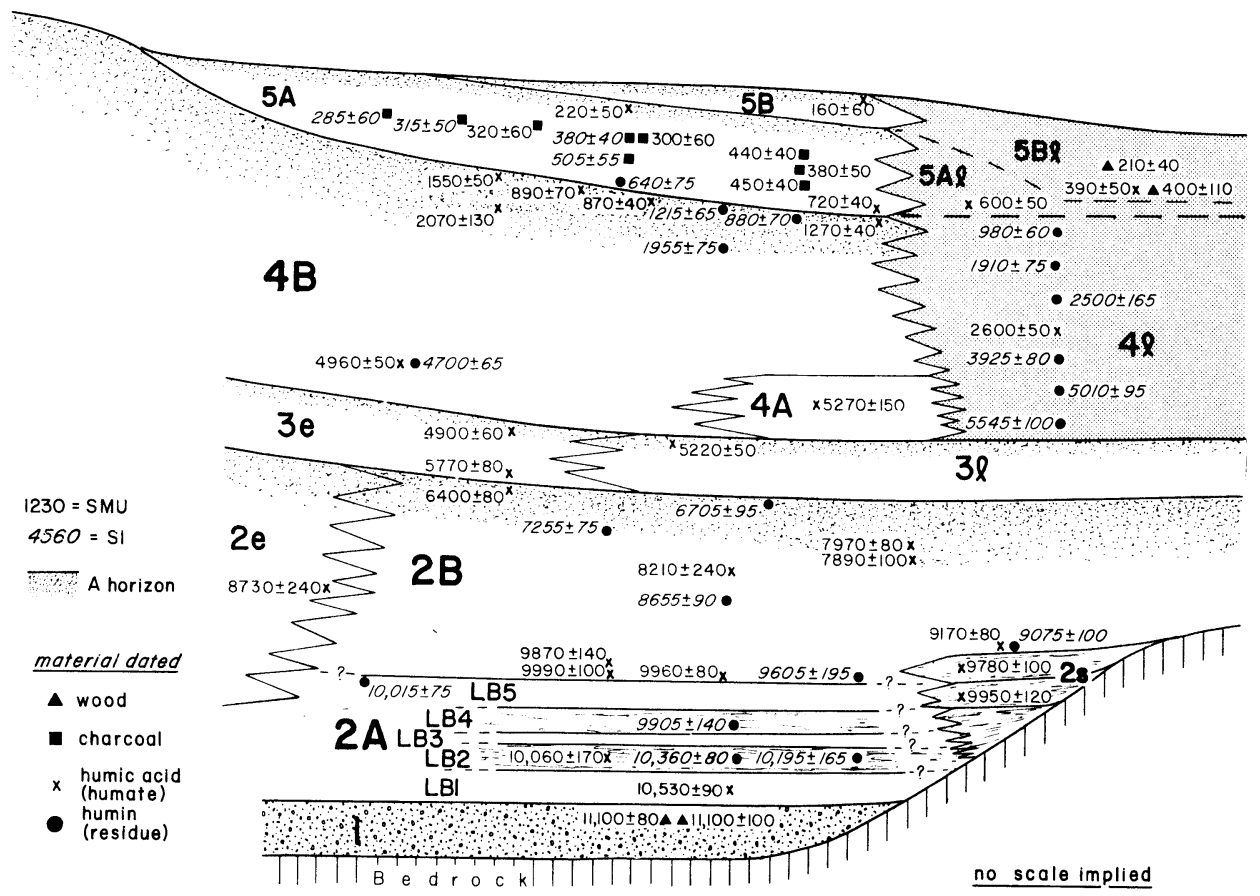

Fig 4. Stratigraphic relationships of the ${ }^{14} \mathrm{C}$ dates determined on extracted humic acids (SMU) and on residual organic matter (SI).

The stable carbon isotope measurements made on the later SMU humate dates are shown in Table 4 and indicate a pattern of changing vegetation. $\delta^{13} \mathrm{C} /{ }^{12} \mathrm{C}$ values between -22.7 and $-23.2 \%$ are observed on marsh sediments in Substratum 2B and 2A indicating the growth of C-3 type grasses and reeds during a period of increased moisture. Values between -14.4 and $-15.7 \%$ occur in the buried A-horizon of substratum $4 \mathrm{~B}$, suggesting growth of C-4 type prairie grasses during this semi-arid period (van der Merve, 1982). In substratum 5B1 the value of $-25.5 \%$ indicates a return of C-3 type vegetation in recent times. This must be considered a local effect.

Correction of the dates for isotope fractionation results in older ages for all humate samples. The increase in age is ca 150 years for samples with $\delta^{13} \mathrm{C} /{ }^{12} \mathrm{C}$ ca $-15 \%$ and ca 30 years for those with $-23 \%$.

\section{DATES ON ORGANIC-RICH SOIL HORIZONS}

${ }^{14} \mathrm{C}$ ages were secured on samples taken from the A-horizons of all principal soils at Lubbock Lake (Fig 4). Most of the samples were from the Firstview Soil, in upper substratum 2B, and the Lubbock Lake Soil, in upper substratum $4 \mathrm{~B}$. Most of these ages can be considered reliable, even in view of the vagaries of dating A-horizons, eg, the five ages from the tops of the buried Lubbock Lake Soil range from $1550-870 \mathrm{yr}$ BP. Such a spread is to be expected in a buried A-horizon which can be subjected to bioturba- 
tion and burial at varying rates and times. However, 3 of these 5 dates lie close together, between 890 and $870 \mathrm{yr}$ BP, and can be compared with 9 dates on charcoal, ranging from 505-285 yr BP, extracted as solid lumps from a hearth in the overlying sediments. Here, the two stratigraphically lowest dates are also the oldest, 505 and 450 years, respectively. Thus, the age difference between the latest stage in the development of the Lubbock Lake Soil and the construction of the hearth averages at least 400 years. This is not a significant difference if one considers mixing in the buried A-horizon and some sedimentation of $5 \mathrm{~A}$ prior to emplacement of the hearth.

The ages from the top of the Firstview Soil (6400-6705 yr BP) are also consistent with an age from overlying Stratum 3 (5770 yr BP), but there are fewer dates from this soil and no check dates on charcoal or wood.

Looking at the ${ }^{14} \mathrm{C}$ dates from the bases of the A-horizons, there is again a consistent age relationship for both the Firstview and the Lubbock Lake Soils. These dates should indicate the beginning of pedogenesis, but their usefulness depends on the local environment. Dates from the base of the Firstview A-horizon (ca $7900 \mathrm{yr}$ BP) are consistent with those from 2B just below the A-horizon and dating between 8500 to $8000 \mathrm{yr}$ BP. This soil formed in a marshy, reducing, organic-rich environment where organic matter from the earliest stages of pedogenesis appears to have been preserved (Holliday, 1985a).

${ }^{14} \mathrm{C}$ dates from the base of the Lubbock Lake Soil A-horizon, however, are considerably younger than ages determined for the underlying substratum 4B (ca 2000 yr BP vs 5000-4000 yr BP, respectively). The Lubbock Lake Soil formed in a well-drained, semi-arid and oxidizing environment in which plant growth is sparse and production of organic matter consequently is slow. Further, due to the oxidizing condition, a significant portion of the organic matter is lost within a few thousand years or even sooner, as studies of organic carbon build-up and decay in the soils at Lubbock Lake suggest (Holliday, 1982). ${ }^{14} \mathrm{C}$ dates from the base of an A-horizon formed in an environment similar to that of the Lubbock Lake Soil will, therefore, only provide an intermediate age between the beginning and end of pedogenesis and have no stratigraphic significance.

\section{CONCLUSIONS}

The applicability of organic-rich sediments and soils for ${ }^{14} \mathrm{C}$ determinations at the Lubbock Lake site is now well demonstrated. The dates from these sediments can serve, essentially, as fixed points in time on a relative time scale for the complete sedimentary column. Dates from buried soil Ahorizons can provide maximum ages for the time of burial and, with some restrictions, provide an estimate for the beginning of pedogenesis. These materials have made it possible to determine the cultural chronology and geochronology in considerably greater detail than would have otherwise been possible using charcoal and wood. The usefulness of Lubbock Lake as a model for the cultural and natural history of the late Quaternary of the region is due in large measure to the successful dating of the abundant organic-rich sediments and soil at the site. 


\section{ACKNOWLEDGMENTS}

Much of the material presented in this paper is from the continuing research of the Lubbock Lake project (Eileen Johnson, Director, The Museum, Texas Tech University) funded by the National Science Foundation (SOC75-14857); BNS7612006; BNS7612006-A01; BNS78-11155), a Grant-in-Aid of Research from Sigma Xi, National Geographic Society, Texas Historical Commission (National Register Program, Center for Field Research (EARTHWATCH), Moody Foundation (Galveston), City and County of Lubbock, and The Museum, Texas Tech University.

The SMU Radiocarbon Laboratory acknowledges support by NSF Grant No. BNS 82-11974.

\section{REFERENCES}

Alexander, S and Price, W, 1980, Radiocarbon dating of the rate of movement of two solifluction lobes in the Ruby Ranges, Yukon territory: Quaternary Research, v 13, no. 3, p 365379.

Allison, L E, 1965, Organic carbon, in Black, C A, ed, Methods of soil analysis: Am Soc Agronomy, Mono ser no. 9, p 1367-1378.

Burleigh, R, 1974, Radiocarbon dating: some practical considerations for the archaeologist: Jour Archaeol Sci, v 1, p 69-87.

Cambell, C A, Paul E A, Rennie, D A and McCallum, K J, 1967, Factors affecting the accuracy of the carbon-dating method in soil humus studies: Soil Sci, v 104, no. 2, p 81-85.

Geyh, M A, Benzler, J H and Roeschmann, G, 1971, Problems of dating Pleistocene and Holocene soils by radiometric methods, in Yaalon, D H, ed, Paleopedology: Origin, nature, and dating of paleosols: Jerusalem, Israel Univ Press, p 63-75.

Goh, K M and Malloy, B P J, 1978, Radiocarbon dating of paleosols using soil organic matter components: Jour Soil Sci, v 29, p 567-573.

Haas, $\mathrm{H}$ and Banewicz, J J, 1980, Radiocarbon dating of bone apatite using thermal-release of $\mathrm{CO}_{2}$ in Stuiver, $\mathrm{M}$ and Kra, RS, eds, Internatl ${ }^{14} \mathrm{C}$ conf, 10 th, Proc: Radiocarbon, v 22, no. $2, \mathrm{p} 537-544$.

Holden, W C, 1974, Historical background of the Lubbock Lake site, in Black, C C, ed, History and prehistory of the Lubbock Lake site: The Mus Jour, v 15, p 11-14.

Holliday, V T, (ms) 1982, Morphological and chemical trends in Holocene soils at the Lubbock Lake archeological site, Texas: PhD dissert, Univ Colorado, Boulder.

1983. Stratigraphy and soils of the Lubbock Lake Landmark area, in Holliday, VT, ed, Guidebook to the Central Llano Estacado: Friends of the Pleistocene, SouthCentral Cell Field Trip, ICASALS and The Museum, Texas Tech Univ, p 25-80.

1985a, Early and Middle Holocene soils at the Lubbock Lake archaeological site, Texas: Catena, v 12, p 61-78.

1985b, Morphology of late Holocene soils at the Lubbock Lake archaeological site, Lubbock County, Texas: Soil Sci Soc America Jour, v 50, no. 4, p 938-946.

1985c, Archaeological geology of the Lubbock Lake site, Southern High Plains of Texas: Bull Geol Soc America, v 96, no. 12, p 1483-1492.

Holliday, V T, Johnson, E, Haas, H and Stuckenrath, R, 1983, Radiocarbon ages from the Lubbock Lake site, 1950-1980: framework for cultural and ecological change on the Southern High Plains: Plains Anthropologist, v 28, no. 101, p 165-182.

1985, Radiocarbon ages from the Lubbock Lake site, 1981-1984: Plains Anthropologist, v 30, no. 110, p 277-291.

Johnson, E, (ms) 1976, Investigations into the zooarchaeology of the Lubbock Lake site: PhD dissert, Texas Tech Univ, Lubbock.

1983, The Lubbock Lake Paleoindian record, in Holliday, VT, ed, Guidebook to the Central Llano Estacado: Friends of the Pleistocene, South-Central Cell Field Trip, ICASALS and The Museum, Texas Tech Univ, p 81-105

Matthews, J A, 1980, Some problems and implications of ${ }^{14} \mathrm{C}$ dates from a Podzol buried beneath an end moraine at Haugabreen, southern Norway: Geog Annaler, v 62A, no. 3-4, p 185-208.

van der Merwe, N J, 1982, Carbon isotopes, photosynthesis, and archaeology: Am Scientist, v 70 , no. 6 , p 596-606.

Michels, J W, 1973, Dating methods in archaeology: New York, Seminar Press, 230 p.

Scharpenseel, H W, 1971 , Radiocarbon dating of soils: Soviet Soil Sci, v 3, p 76-83.

1979, Soil fraction dating, in Berger, R and Suess, H E, eds, Radiocarbon dating, Internatl ${ }^{14} \mathrm{C}$ conf, 9 th, Proc: Berkeley/Los Angeles, Univ California Press, p 277-283. 
Sheppard, J C, Ali, S Y and Mehringer, P J, Jr, 1979, Radiocarbon dating of organic components of sediments and peats, in Berger, $\mathrm{R}$ and Suess, $\mathrm{H}$ E, eds, Radiocarbon dating, Internat ${ }^{14} \mathrm{C}$ conf, 9 th, Proc: Berkeley/Los Angeles, Univ California Press, p 284-305.

Stafford, T W, 1981, Alluvial geology and archaeological potential of the Texas Southern High Plains: Am Antiquity, v 46, p 548-565.

Taylor, R E and Slota, P J, Jr, 1979, Fraction studies on marine shell and bone samples for radiocarbon analysis, in Berger, $\mathrm{R}$ and Suess, $\mathrm{H}$ E, eds, Radiocarbon dating, Internat ${ }^{14} \mathrm{C}$ conf, 9th, Proc: Berkeley/Los Angeles, Univ California Press, p 422-432. 